\title{
Safety of combination therapy with two bDMARDs in patients with rheumatoid arthritis: a systematic review and meta-analysis
}

Gonçalo Boleto (1), Lukshe Kanagaratnam (2,3), Moustapha Dramé (2,3), Jean-Hugues Salmon $(1,3)$

(1) Rheumatology Department, Maison Blanche Hospital, Reims University Hospitals, 51092, Reims, France

(2) Department of Research and Innovation, Robert Debré Hospital, Reims University Hospitals, 51092, Reims, France

(3) University of Reims Champagne-Ardenne, Faculty of Medicine, EA 3797, 51095, Reims, France

\section{Corresponding author: Dr. Jean-Hugues Salmon}

Service de Rhumatologie, Hôpital Maison Blanche, CHU de Reims

45 Rue Cognacq-Jay

51100 Reims, France

Telephone: + 33326784470 Fax: + 33310736701

e-mail: jhsalmon@chu-reims.fr

Word count: Abstract words: 250; manuscript words: 2809; references: 44; number of tables: 1; number of Figures: 3; Supplementary material: $\mathbf{3}$ tables and $\mathbf{3}$ figures.

Keywords: rheumatoid arthritis-drug therapy; drug tolerance; drug therapy, combination; meta-analysis as topic

\section{Contributorship:}

-Study design: GB, LK, MD, JHS

-Data collection: GB, JHS

-Data analysis and interpretation: GB, LK, JHS

-Drafting the article: GB, JHS

-Critical revision of the article: GB, JHS

-Final approval of the version to be published: GB, LK, MD, JHS

Conflict of interest: None declared.

Funding: No specific funding was received from any bodies in the public, commercial or not-for-profit sectors to carry out the work described in this manuscript. 


\begin{abstract}
Objectives: We performed a systematic review and meta-analysis of the current literature to assess the safety of combining two biologic disease-modifying antirheumatic drugs (bDMARDs) in the treatment of rheumatoid arthritis (RA).
\end{abstract}

Methods: We systematically searched for controlled studies evaluating safety in patients with RA treated with two bDMARDs independently of dose-regimen. Databases used were MEDLINE (via Pubmed), EMBase, Cochrane Library, Scopus, ClinicalTrials.gov, and the WHO International Clinical Trials Registry platform. A meta-analysis was performed between groups on combination therapy and patients on single therapy using random effects model calculating odds ratio (OR) as well as $95 \%$ confidence interval (CI). The primary outcome was the rate of serious adverse events (SAEs).

Results: Six studies with a total of 623 patients (410 on combination therapy and 213 on single therapy) were included. Median follow-up was 9.5 months (range 6-12 months). There was a significant increase in SAEs in the combination group (14.9 vs 6.0\%, OR 2.51, 95\% CI 1.29-4.89, $\mathrm{I}^{2} 0 \%$ ) as well as in total adverse events (94.6 vs $89.1 \%$, OR 2.07, 95\% CI 1.11-3.86, $\mathrm{I}^{2} 0 \%$ ). When performing subgroup analysis in patients receiving only full-dose of both bDMARDs there was a significant increase in serious infections (6.7 vs $0.6 \%$, OR 5.58, 95\% CI 1.25-24.90, $\left.\mathrm{I}^{2} 0 \%\right)$ and the risk of SAEs remained significantly higher (17.1 vs $6.2 \%$, OR $2.72,95 \%$ CI $1.30-5.69, \mathrm{I}^{2} 0 \%$ ).

Conclusion: Our findings suggest that combination therapy with two bDMARDs in RA appears to increase the risk of SAEs during the first twelve months of treatment. 


\section{Introduction}

Since the advent of biologic disease-modifying antirheumatic drugs (bDMARDs) the management of patients with rheumatoid arthritis (RA) has improved dramatically. Several bDMARDs that target different key players of the immune-regulatory pathways, such as proinflammatory cytokines and T and B cells, are currently available for RA (1). To date, there are numerous efficacious bDMARDs including tumor necrosis alpha inhibitors (TNFi) (infliximab, etarnercept, adalimumab, certolizumab, golimumab), an interleukin-1 (IL-1) receptor antagonist (anakinra), interleukin-6 (IL-6) pathway inhibitors (tocilizumab, sarilumab, sirukimab), a B-cell depleting agent (rituximab) and an inhibitor of T-cell costimulation (abatacept). Current therapeutic goals are aimed at achieving remission as assessed by different disease activity scores $(2,3)$ since this will prevent progression of joint damage and deformity (4). However, about $20 \%$ to $40 \%$ of patients treated with biologic therapies fail to achieve remission due to acquired therapeutic resistance, secondary failure or intolerance, consequently requiring additional treatment (5-8).

Combining anticytokine agents has been evaluated in animal models of arthritis resulting in synergistic improvement in the symptoms when compared to treatment with either agents alone (9,10). Moreover, recent data evaluating biologics that simultaneously target two molecules (dual target-directed agents) suggest it to be a promising strategy for RA (11-14).

Patients with RA are prone to infection (15) and several studies confirmed the increased risk of infectious events among patients treated with biologic agents (16-18). Hence, the safety and tolerability of combining different biologic agents is one of the major concerns of this treatment approach. Thus, we performed a systematic review and metaanalysis of the current literature to assess the safety of combining two bDMARDs in the treatment of patients with RA. 


\section{Methods}

\section{Search strategy}

We performed a systematic review of the literature with meta-analysis of studies in which any combination of two bDMARDs approved for therapy in RA was assessed in the following databases: MEDLINE (via PubMed), EMBase, the Cochrane Library, Scopus, ClinicalTrials.gov, and the WHO International Clinical Trials Registry platform. The review was performed in accordance with the Preferred Reporting Items for Systematic Reviews and Meta-Analyses (PRISMA) Guidelines (19). Keywords used were "rheumatoid arthritis", "biological products" and "combination" (figure 1). No limits were applied. We screened reference lists of relevant articles to ensure that no relevant publications were overlooked. The research clinical question was formulated according to the PICOs (Population, Intervention, Comparison, Outcome and Study design) method (20) (supplementary table 1).

\section{Study selection}

Studies which met the following criteria were included: (1) randomized, double-blind, placebo-controlled clinical trials (RCTs); or (2) observational or non-randomized comparative studies that recorded safety events; and (3) patients aged 18 years or over with diagnosed RA as defined by the ACR 1987 and/or ACR/EULAR $2010(21,22)$ and (4) studies in patients treated with at least two bDMARDs (including infliximab, etarnercept, adalimumab, certolizumab, golimumab, anakinra, abatacept, rituximab, and tocilizumab) independently of dose-regimen. The titles and abstracts of articles identified were reviewed independently by two rheumatologists (GB, JHS) and discordant evaluations were reviewed until consensus was reached.

\section{Data extraction and management}

Two reviewers (GB, JHS) independently extracted data for each study, including characteristics of the studies, demographic and disease characteristics of patients included in each study, evaluation criteria for safety, results and author's conclusions. Risk of bias assessment for RCTs was performed using the Cochrane risk of bias tool as described in the Cochrane Handbook (23). Risk of bias for observational studies was 
examined using a pre-specified scale based on the Newcastle-Ottawa scale (24). A serious adverse event (SAE) was defined as an adverse event that met any of the following criteria: was fatal; was life threatening; resulted in or prolonged hospitalization; resulted in persistent or marked disability or incapacity; was cancer; resulted in an overdose; resulted in the development of drug dependence or drug misuse; or was an important medical event. Infections were considered serious if they met criteria for an SAE or required intravenous antibiotics (25).

\section{Statistical analysis}

Studies were included in the quantitative synthesis if numerical data were extractable. The primary outcome was the rate of serious adverse events independently of doseregimen (full and tapered dosages). Secondary outcomes were the risk of overall adverse events, overall infections and serious infections independently of dose-regimen. Moreover, we performed subgroup analysis of the primary and secondary outcomes on the studies in which patients received exclusively full dosage of bDMARDs as well as in studies in which patients received tapered dosage of at least one bDMARD. Extracted data were presented as number and percentage for qualitative variables, and as mean and standard deviation (or median and miminum, maximum) for quantitative variables. Heterogeneity between studies was assessed using the Cochran Q statistic and $\mathrm{I}^{2}$ test. A random effects model was used independently of the existence or absence of heterogeneity between the results of the studies because results of studies with different design and patients' characteristics were pooled. The Mantel-Haenszel method was used with a random effects model, to generate an Odds ratio (OR) and 95\% confidence intervals (CIs) for all included studies. Sensitivity analyses were performed. All analyses were performed using $\mathrm{R}$ version 3.1.2 ( $\mathrm{R}$ Foundation for Statistical Computing, Vienna, Austria).

\section{Results}

\section{Literature search results and study characteristics}

Initially, 719 potentially relevant studies were screened and 713 were excluded (figure 1). After manually searching reference lists, reports of 6 studies were included by 
consensus for qualitative synthesis; they were all included for meta-analysis. Among these six studies, five were clinical trials (26-30) and one was a cohort study (31). Median follow-up was 9.5 months (range 6-12 months). Safety was the primary outcome in three studies (3/6) $(27,29,31)$. bDMARDs used in combination therapy were: TNFi and anakinra in one study (26), TNFi and abatacept in two studies $(27,28)$, TNFi and rituximab in two studies(29,31), abatacept and anakinra in one study (27) and rituximab and tocilizumab in one study(30).

Table 1 gives a brief overview of these studies. Risk of bias in all studies was moderate to good (supplementary table 2 and 3 ).

This systematic review involved 623 patients: 410 patients were treated with the combination of two bDMARDs (combination group) and 213 patients were treated with one bDMARD alone or one bDMARD plus placebo (control group).

2. Safety of combination therapy with two bDMARDs in RA patients independently of dose-regimen (full and tapered dosages)

\subsection{Overall adverse events (AEs)}

Five studies (26-30) compared overall AEs between combination and control groups and were included in meta-analysis (figure 2A). One study (31) was excluded due to unavailable data on overall AEs. Pooled results showed an increase in overall adverse events in patients receiving combination therapy with two bDMARDs as compared to control group (94.6 vs $89.1 \%$, OR 2.07, 95\% CI 1.11-3.86, I² 0\%).

\subsection{Serious adverse events (SAEs)}

Five studies (26-30) that recorded SAEs were included in the meta-analysis (figure 2B). One study was excluded due to unavailable data on SAEs (31). On pooled analysis there was an increase in SAEs in the combination group as compared to control group (14.9 vs $6.0 \%$, OR 2.51, 95\% CI 1.29-4.89, I² 0\%). Among the studies which recorded mortality (26-29) only one death was recorded in the combination group in the study of Genovese et al (26).

\subsection{Overall incidence of infections}

Five studies $(26,27,29-31)$ that recorded incidence of infections between combination and control groups were included in the meta-analysis (figure 2C). One study (28) was 
excluded due to unavailable data on overall infectious events. Although four of the studies were randomized trials and one was observational, we considered that there was enough similarity and the outcomes were hard enough not to be influenced by the design. Pooled analysis showed no increased risk of infections between the two groups (52.9 vs $46.6 \%$, OR $1.18,95 \%$ CI $\left.0.81-1.74, \mathrm{I}^{2} 0 \%\right)$.

\subsection{Serious infections}

Six studies (26-31) that recorded serious infections were meta-analyzed (figure 2D). We observed an increase not reaching statistic significance in serious infections in combination group as compared to control group (5.4 vs $0.47 \%$, OR 3.46, 95\% CI 1.00$\left.11.97, \mathrm{I}^{2} 0 \%\right)$.

\subsection{Total neoplasms}

Only two studies $(27,31)$ recorded neoplastic events during follow-up and therefore meta-analysis was not feasible. In the study of Weinblatt et al (27) there was an increased rate of neoplasms in the combination group (abatacept plus TNFi or abatacept plus anakinra) as compared to control group (TNFi or anakinra plus placebo) (6.8 vs $1.6 \%)$. In the study of Blank et al (31) there were no cases of neoplasms in both groups (rituximab plus etanercept vs etanercept alone).

Sensitivity analysis on overall infectious events and serious infections independently of dose-regimen were performed after exclusion of the only non-randomized study (31) (see supplementary figure 1).

3. Safety of combination therapy with two bDMARDs in RA patients receiving only full dosage of bDMARDs

When performing subgroup meta-analysis on the studies in which patients received exclusively full dosage of bDMARDs (figure 3), the risk of SAEs in the combination group remained significantly higher (17.1 vs 6.2\%, OR 2.72, 95\% CI 1.30-5.69, I ${ }^{2} 0 \%$ ) $(26,27,29)$ (figure 3A). On the other hand, the risk of overall AEs was not statistically different between the two groups (94.4 vs $89.0 \%$, OR $2.15,95 \%$ CI $1.00-4.62, \mathrm{I}^{2} 0 \%$ ) (figure 3B). Regarding infectious events, the risk of serious infections remained significantly higher in the combination group when compared to control group (6.7 vs 
$0.6 \%$, OR 5.58, 95\% CI 1.25-24.90, $\mathrm{I}^{2} 0 \%$ ). Conversely, the risk of overall infections was not different between the two groups (55.6 vs $46.0 \%$, OR $1.28,95 \%$ CI $0.85-1.94$, $\left.\mathrm{I}^{2} 0 \%\right)$.

Sensitivity analysis on overall infectious events and serious infections in patients receiving exclusively full dosage of bDMARDs were performed after exclusion of the only non-randomized study (31) (see supplementary figure 2).

\section{Safety of combination therapy with two bDMARDs in RA patients receiving tapered dosage of at least one bDMARD}

We performed subgroup meta-analysis on the studies in which patients received tapered doses of at least one of the bDMARDs in the combination group (supplementary figure 3). Results showed no statistical significance in the risk of overall AEs (94.6 vs 89.9\%, OR 1.89, 95\% CI 0.76-4.69, I I 0\%), SAEs (12.3 vs 3.4\%, OR 2.36, 95\% CI 0.68-8.14, $\mathrm{I}^{2} 8 \%$ ) or serious infections (3.7 vs $0.0 \%$, OR 2.54 , 95\% CI $0.42-15.26$, $\left.\mathrm{I}^{2} 0 \%\right)$. Due to insufficient, data meta-analysis of the risk of overall infectious events was not performed.

\section{Discussion}

To our knowledge, this is the first systematic review with meta-analysis evaluating the safety of the combination of two bDMARDs in patients with RA. Our findings confirm some previous individual studies results suggesting increased risks of SAEs in particular serious infections in RA patients receiving two bDMARDs concomitantly (26-28).

RA confers a substantially increased risk of morbidity and mortality related to cardiovascular, respiratory, and infectious diseases $(32,33)$. A recent study reported that $8 \%$ of patients with RA require hospital admission each year due to serious infections (15). A previous network meta-analysis found that in the short term biologics were associated with statistically significant higher rates of total AEs and serious infections (34). Recently, data from the British Society for Rheumatology Biologics Register for Rheumatoid Arthritis (BSRBR-RA) including 19282 patients confirmed higher rates of 
serious infections with an incidence of 5.51 cases per 100 patients years (35). Hence, it was hypothesized that combining different bDMARDs could increase the risk of adverse events and serious infections.

Data regarding safety of combination therapy with different bDMARDs in RA are scarce. Our meta-analysis showed a modest but increased risk of total AEs, SAEs but not in overall infections and serious infections in patients treated with two bDMARDs concomitantly. Interestingly, the risk of serious infections was significantly higher in patients receiving only full dose of both bDMARDs thus suggesting that using higher doses may be associated with higher AEs in particular serious infections. Indeed, when we performed some exploratory analysis on the subgroup of patients who received tapered doses of at least one of the bDMARDs, we did not observe any significant increase in overall AEs, SAEs or serious infections. This should be interpreted with caution because of the low number of events with wide confidence intervals making these statistical results unstable. Nonetheless, the risk of the association of tapered doses of bDMARDs should deserve further investigation in order to clarify whether this could be a safe approach in selected RA patients. Of note, our literature search highlighted one study not fulfilling our selection criteria for meta-analysis showing that the safety profile of rituximab in combination with another bDMARD was similar with that reported for rituximab with other non biologic DMARD (36). However, this was an uncontrolled study.

The overall incidence of SAEs in the included studies in our systematic review was 14.9\%. The incidence of SAEs reported in previous clinical trials of bDMARDs used either in monotherapy or in association with other csDMARDs (conventional synthetic DMARDs) seems to be slightly lower than that observed in our study: 11\% (11/88) with infliximab (5), 12\% (33/274) with etanercept (37), 6\% (13/212) with tocilizumab (38), $10.5 \%(27 / 258)$ with abatacept (39), $10 \%$ (4/40) with rituximab (40) and $7.7 \%$ (86/1116) with anakinra (41).

Efficacy of combination therapy has also been evaluated in the included studies. Overall, data from the five clinical trials included (26-30) showed modest clinical effects with no clear evidence of an efficacy advantage in RA patients receiving combination therapy. Yet, when focusing on the only observational study included (31) combination therapy (rituximab and etanercept) seems to show clinical and biological benefits in patients with RA in a "real-life" setting. Since there are substantial differences in RA patients characteristics between randomized-controlled trials and 
observational studies (42) the question of efficacy of a combination strategy should deserve further investigation in real-world settings.

Our systematic review with meta-analysis has several strengths. The studies we included showed high-quality scores. Furthermore, most of the studies were randomized clinical trials with only one observational controlled study (31). Indeed, when performing sensitivity analysis after exclusion of the observational study the risk of adverse events remained stable. However, limitations of this study should also be considered when interpreting the findings, in particular the small number of studies included, different combination therapy approaches used, unavailable data on average dose of corticosteroid and methotrexate at inclusion and short follow-up period up to 12 months.

This study is timely since dual-target directed agents targeting simultaneously different cytokines involved in the pathogenesis of RA are currently being developed $(43,44)$. In fact, dual inhibition of TNF and interleukin-17A produced an acceptable safety profile in patients with RA when compared to TNF inhibition with adalimumab alone. However, safety data on dual-target agents in RA are scarce. Therefore any direct comparison between dual-target with bi-specific antibodies and combination therapy with two separate agents should be taken with caution.

\section{Conclusion}

In summary, our findings suggest that combination therapy with two bDMARDs appears to increase the risk of SAEs during the first six to twelve months of treatment especially in patients receiving full dose of both bDMARDs. Using tapered doses of bDMARDs seems to be a safer approach; further studies are warranted to confirm this signal. Therefore, clinicians should assess the risk/benefit ratio before considering a combination therapy in the management of patients with RA. 


\section{References}

1. Smolen JS, Landewé R, Bijlsma J, Burmester G, Chatzidionysiou K, Dougados M, et al. EULAR recommendations for the management of rheumatoid arthritis with synthetic and biological disease-modifying antirheumatic drugs: 2016 update. Ann Rheum Dis. 2017 Jun;76(6):960-77.

2. Prevoo ML, van 't Hof MA, Kuper HH, van Leeuwen MA, van de Putte LB, van Riel PL. Modified disease activity scores that include twenty-eight-joint counts. Development and validation in a prospective longitudinal study of patients with rheumatoid arthritis. Arthritis Rheum. 1995 Jan;38(1):44-8.

3. Smolen JS, Breedveld FC, Schiff MH, Kalden JR, Emery P, Eberl G, et al. A simplified disease activity index for rheumatoid arthritis for use in clinical practice. Rheumatol Oxf Engl. 2003 Feb;42(2):244-57.

4. Kavanaugh A, Fleischmann RM, Emery P, Kupper H, Redden L, Guerette B, et al. Clinical, functional and radiographic consequences of achieving stable low disease activity and remission with adalimumab plus methotrexate or methotrexate alone in early rheumatoid arthritis: 26-week results from the randomised, controlled OPTIMA study. Ann Rheum Dis. 2013 Jan;72(1):64-71.

5. Lipsky PE, van der Heijde DM, St Clair EW, Furst DE, Breedveld FC, Kalden JR, et al. Infliximab and methotrexate in the treatment of rheumatoid arthritis. AntiTumor Necrosis Factor Trial in Rheumatoid Arthritis with Concomitant Therapy Study Group. N Engl J Med. 2000 Nov 30;343(22):1594-602.

6. Weinblatt ME, Keystone EC, Furst DE, Moreland LW, Weisman MH, Birbara $\mathrm{CA}$, et al. Adalimumab, a fully human anti-tumor necrosis factor alpha monoclonal antibody, for the treatment of rheumatoid arthritis in patients taking concomitant methotrexate: the ARMADA trial. Arthritis Rheum. 2003 Jan;48(1):35-45.

7. Keystone EC, Schiff MH, Kremer JM, Kafka S, Lovy M, DeVries T, et al. Onceweekly administration of $50 \mathrm{mg}$ etanercept in patients with active rheumatoid arthritis: results of a multicenter, randomized, double-blind, placebo-controlled trial. Arthritis Rheum. 2004 Feb;50(2):353-63.

8. Weinblatt ME, Kremer JM, Bankhurst AD, Bulpitt KJ, Fleischmann RM, Fox RI, et al. A trial of etanercept, a recombinant tumor necrosis factor receptor:Fc fusion protein, in patients with rheumatoid arthritis receiving methotrexate. $\mathrm{N}$ Engl J Med. 1999 Jan 28;340(4):253-9.

9. Bendele AM, Chlipala ES, Scherrer J, Frazier J, Sennello G, Rich WJ, et al. Combination benefit of treatment with the cytokine inhibitors interleukin-1 receptor antagonist and PEGylated soluble tumor necrosis factor receptor type I in animal models of rheumatoid arthritis. Arthritis Rheum. 2000 Dec;43(12):264859. 
10. Feige U, Hu YL, Gasser J, Campagnuolo G, Munyakazi L, Bolon B. Antiinterleukin-1 and anti-tumor necrosis factor-alpha synergistically inhibit adjuvant arthritis in Lewis rats. Cell Mol Life Sci CMLS. 2000 Sep;57(10):1457-70.

11. Veri M-C, Burke S, Huang L, Li H, Gorlatov S, Tuaillon N, et al. Therapeutic control of B cell activation via recruitment of Fcgamma receptor IIb (CD32B) inhibitory function with a novel bispecific antibody scaffold. Arthritis Rheum. $2010 \mathrm{Jul} ; 62(7): 1933-43$.

12. Kanakaraj P, Puffer BA, Yao X-T, Kankanala S, Boyd E, Shah RR, et al. Simultaneous targeting of TNF and Ang2 with a novel bispecific antibody enhances efficacy in an in vivo model of arthritis. mAbs. 2012 Oct;4(5):600-13.

13. Liu M, Xie M, Jiang S, Liu G, Li L, Liu D, et al. A novel bispecific antibody targeting tumor necrosis factor $\alpha$ and ED-B fibronectin effectively inhibits the progression of established collagen-induce arthritis. J Biotechnol. 2014 Sep 30;186:1-12.

14. Kim Y, Yi H, Jung H, Rim YA, Park N, Kim J, et al. A Dual Target-directed Agent against Interleukin-6 Receptor and Tumor Necrosis Factor $\alpha$ ameliorates experimental arthritis. Sci Rep. 2016 Feb 4;6:20150.

15. Subesinghe S, Rutherford AI, Ibrahim F, Harris H, Galloway J. A large two-centre study in to rates of influenza and pneumococcal vaccination and infection burden in rheumatoid arthritis in the UK. BMC Musculoskelet Disord. 2016 04;17:322.

16. Curtis JR, Patkar N, Xie A, Martin C, Allison JJ, Saag M, et al. Risk of serious bacterial infections among rheumatoid arthritis patients exposed to tumor necrosis factor alpha antagonists. Arthritis Rheum. 2007 Apr;56(4):1125-33.

17. Galloway JB, Hyrich KL, Mercer LK, Dixon WG, Fu B, Ustianowski AP, et al. Anti-TNF therapy is associated with an increased risk of serious infections in patients with rheumatoid arthritis especially in the first 6 months of treatment: updated results from the British Society for Rheumatology Biologics Register with special emphasis on risks in the elderly. Rheumatol Oxf Engl. 2011 Jan;50(1):12431.

18. Askling J, Fored CM, Brandt L, Baecklund E, Bertilsson L, Feltelius N, et al. Time-dependent increase in risk of hospitalisation with infection among Swedish RA patients treated with TNF antagonists. Ann Rheum Dis. 2007 Oct;66(10):1339-44.

19. PRISMA. Transparent reporting of systematic reviews and meta-analysis [Internet]. [cited 2018 Apr 2]. Available from: http://www.prisma-statement.org/

20. Cochrane Linked Data. PICO ontology [Internet]. [cited 2018 Apr 2]. Available from: https://linkeddata.cochrane.org/pico-ontology

21. Arnett FC, Edworthy SM, Bloch DA, McShane DJ, Fries JF, Cooper NS, et al. The American Rheumatism Association 1987 revised criteria for the classification of rheumatoid arthritis. Arthritis Rheum. 1988 Mar;31(3):315-24. 
22. Aletaha D, Neogi T, Silman AJ, Funovits J, Felson DT, Bingham CO, et al. 2010 Rheumatoid arthritis classification criteria: an American College of Rheumatology/European League Against Rheumatism collaborative initiative. Arthritis Rheum. 2010 Sep;62(9):2569-81.

23. Cochrane Bias. Assessing Risk of Bias in Included Studies [Internet]. [cited 2018 Apr 2]. Available from: https://methods.cochrane.org/bias/assessing-risk-biasincluded-studies

24. Ottawa Hospital Research Institute. The Newcastle-Ottawa Scale (NOS) for assessing the quality of nonrandomised studies in meta-analyses [Internet]. [cited 2018 Jul 28]. Available from:

http://www.ohri.ca/programs/clinical_epidemiology/oxford.asp

25. Lacoste-Roussillon C, Pouyanne P, Haramburu F, Miremont G, Bégaud B. Incidence of serious adverse drug reactions in general practice: a prospective study. Clin Pharmacol Ther. 2001 Jun;69(6):458-62.

26. Genovese MC, Cohen S, Moreland L, Lium D, Robbins S, Newmark R, et al. Combination therapy with etanercept and anakinra in the treatment of patients with rheumatoid arthritis who have been treated unsuccessfully with methotrexate. Arthritis Rheum. 2004 May;50(5):1412-9.

27. Weinblatt M, Combe B, Covucci A, Aranda R, Becker JC, Keystone E. Safety of the selective costimulation modulator abatacept in rheumatoid arthritis patients receiving background biologic and nonbiologic disease-modifying antirheumatic drugs: A one-year randomized, placebo-controlled study. Arthritis Rheum. 2006;54(9):2807-16.

28. Weinblatt M, Schiff M, Goldman A, Kremer J, Luggen M, Li T, et al. Selective costimulation modulation using abatacept in patients with active rheumatoid arthritis while receiving etanercept: a randomised clinical trial. Ann Rheum Dis. 2007 Feb;66(2):228-34.

29. Greenwald MW, Shergy WJ, Kaine JL, Sweetser MT, Gilder K, Linnik MD. Evaluation of the safety of rituximab in combination with a tumor necrosis factor inhibitor and methotrexate in patients with active rheumatoid arthritis: results from a randomized controlled trial. Arthritis Rheum. 2011 Mar;63(3):622-32.

30. ClinicalTrials.gov. A Study of Combination Treatment With MabThera (Rituximab) and RoActemra (Tocilizumab) Versus RoActemra in Patients With Rheumatoid Arthritis With an Incomplete Response to Methotrexate [Internet]. [cited 2018 Jul 28]. Available from: https://clinicaltrials.gov/ct2/show/NCT00845832

31. Blank N, Max R, Schiller M, Briem S, Lorenz H-M. Safety of combination therapy with rituximab and etanercept for patients with rheumatoid arthritis. Rheumatol Oxf Engl. 2009 Apr;48(4):440-1.

32. Bongartz T, Sutton AJ, Sweeting MJ, Buchan I, Matteson EL, Montori V. AntiTNF antibody therapy in rheumatoid arthritis and the risk of serious infections and 
malignancies: systematic review and meta-analysis of rare harmful effects in randomized controlled trials. JAMA. 2006 May 17;295(19):2275-85.

33. Avouac J, Amrouche F, Meune C, Rey G, Kahan A, Allanore Y. Mortality profile of patients with rheumatoid arthritis in France and its change in 10 years. Semin Arthritis Rheum. 2017;46(5):537-43.

34. Singh JA, Wells GA, Christensen R, Tanjong Ghogomu E, Maxwell L, Macdonald JK, et al. Adverse effects of biologics: a network meta-analysis and Cochrane overview. Cochrane Database Syst Rev. 2011 Feb 16;(2):CD008794.

35. Rutherford AI, Subesinghe S, Hyrich KL, Galloway JB. Serious infection across biologic-treated patients with rheumatoid arthritis: results from the British Society for Rheumatology Biologics Register for Rheumatoid Arthritis. Ann Rheum Dis. 2018 Jun;77(6):905-10.

36. Rigby WFC, Mease PJ, Olech E, Ashby M, Tole S. Safety of rituximab in combination with other biologic disease-modifying antirheumatic drugs in rheumatoid arthritis: An open-label study. J Rheumatol. 2013;40(5):599-604.

37. Emery P, Breedveld FC, Hall S, Durez P, Chang DJ, Robertson D, et al. Comparison of methotrexate monotherapy with a combination of methotrexate and etanercept in active, early, moderate to severe rheumatoid arthritis (COMET): a randomised, double-blind, parallel treatment trial. Lancet Lond Engl. 2008 Aug 2;372(9636):375-82.

38. Smolen JS, Beaulieu A, Rubbert-Roth A, Ramos-Remus C, Rovensky J, Alecock E, et al. Effect of interleukin-6 receptor inhibition with tocilizumab in patients with rheumatoid arthritis (OPTION study): a double-blind, placebo-controlled, randomised trial. Lancet Lond Engl. 2008 Mar 22;371(9617):987-97.

39. Genovese MC, Becker J-C, Schiff M, Luggen M, Sherrer Y, Kremer J, et al. Abatacept for rheumatoid arthritis refractory to tumor necrosis factor alpha inhibition. N Engl J Med. 2005 Sep 15;353(11):1114-23.

40. Edwards JCW, Szczepanski L, Szechinski J, Filipowicz-Sosnowska A, Emery P, Close DR, et al. Efficacy of B-cell-targeted therapy with rituximab in patients with rheumatoid arthritis. N Engl J Med. 2004 Jun 17;350(25):2572-81.

41. Fleischmann RM, Schechtman J, Bennett R, Handel ML, Burmester G-R, Tesser J, et al. Anakinra, a recombinant human interleukin-1 receptor antagonist ( $\mathrm{r}-$ metHuIL-1ra), in patients with rheumatoid arthritis: A large, international, multicenter, placebo-controlled trial. Arthritis Rheum. 2003 Apr;48(4):927-34.

42. Kilcher G, Hummel N, Didden EM, Egger M, Reichenbach S, GetReal Work Package 4. Rheumatoid arthritis patients treated in trial and real world settings: comparison of randomized trials with registries. Rheumatol Oxf Engl. 2018 01;57(2):354-69.

43. Genovese MC, Weinblatt ME, Aelion JA, Mansikka HT, Peloso PM, Chen K, et al. ABT-122, a Bispecific DVD-Immunoglobulin Targeting TNF- and IL-17A, in 
RA With Inadequate Response to Methotrexate: A Randomized, Double-Blind Study. Arthritis Rheumatol Hoboken NJ. 2018 May 31;

44. Genovese MC, Weinblatt ME, Mease PJ, Aelion JA, Peloso PM, Chen K, et al. Dual inhibition of tumour necrosis factor and interleukin-17A with ABT-122: open-label long-term extension studies in rheumatoid arthritis or psoriatic arthritis. Rheumatol Oxf Engl. 2018 Jul 18; 


\section{Figure legends}

Figure 1. Flowchart of the literature search.

Figure 2. Forest plot of mean differences between combination therapy and controls ('monotherapy') in overall adverse events (A), serious adverse events (B), overall infectious events (C), serious infections (D) independently of dose-regimen (full and tapered dosages).

Figure 3. Forest plot of mean differences between combination therapy and controls ('monotherapy') in overall adverse events (A), serious adverse events (B), overall infectious events $(\mathrm{C})$, serious infections $(\mathrm{D})$ in patients receiving only full dosage of biologic disease-modifying antirheumatic drugs.

\section{Table legends}

Table 1. Summary of studies included in meta-analysis 


$$
\text { and combination }
$$

("rheumatoid arthritis"/exp OR "rheumatoid arthritis") AND

("biological product"/exp OR

"biological product") AND

("combination drug ther apy"/exp

OR "combination drug ther apy")

$(\mathrm{n}=286)$ $(\mathrm{n}=164)$

\begin{tabular}{c} 
Biologics AND rheumatoid ar thritis \\
AND combination \\
$(\mathrm{n}=9)$ \\
\hline
\end{tabular}

\section{SCOPUS}

Biologics AND "rheumatoid arthritis" AND combination AND

$$
\text { "drug ther apy" }
$$

$(\mathrm{n}=425)$

Duplicates removed $(\mathrm{n}=104)$
WHO

Condition: rheumatoid arthritis Other terms: biologics AND

$$
\text { combination }
$$

iologics AND AND combination

\section{$(\mathrm{n}=78)$}

Records excluded after review of title $\mathcal{E}$ abstracts

Wot in English or French ( $\mathrm{n}=65$ )

No treatment of interest $(\mathrm{n}=359)$

Review articles $(\mathrm{n}=145)$

Editorials $(\mathrm{n}=132)$

Case reports $(\mathrm{n}=1)$

Guidelines $(\mathrm{n}=23)$

Conference abstracts $(\mathrm{n}=19)$

No safety outcomes ( $\mathrm{n}=36)$

$B$ asic research ( $n=14)$

Patients do not have $\mathrm{RA}(\mathrm{n}=64)$

No control group (n=1)

Recordsincluded in qualitative synthesis 


\section{Odds Ratio}

\begin{tabular}{|c|c|c|c|c|}
\hline Genovese et al. (2004) & 153 & 162 & 72 & 80 \\
\hline Weinblatt et al. (2006) & 98 & 103 & 57 & 64 \\
\hline Weinblatt et al. (2007) & 79 & 85 & 32 & 36 \\
\hline Greenwald et al. (2013) & 31 & 33 & 15 & 18 \\
\hline NCT0084583 & 21 & 21 & 3 & 3 \\
\hline ects & & 404 & & 20 \\
\hline
\end{tabular}

Heterogeneity: I-squared $=0 \%$, tau-squared $=0, p=0.9437$

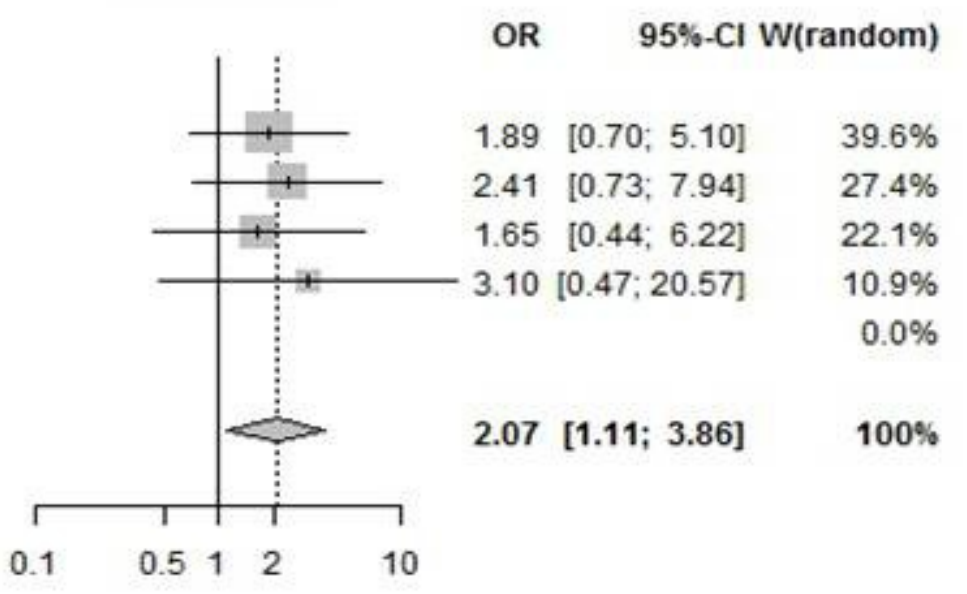

B

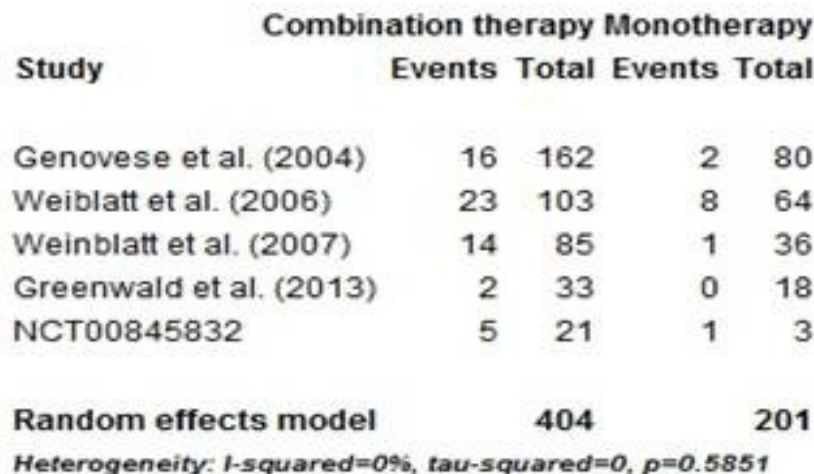

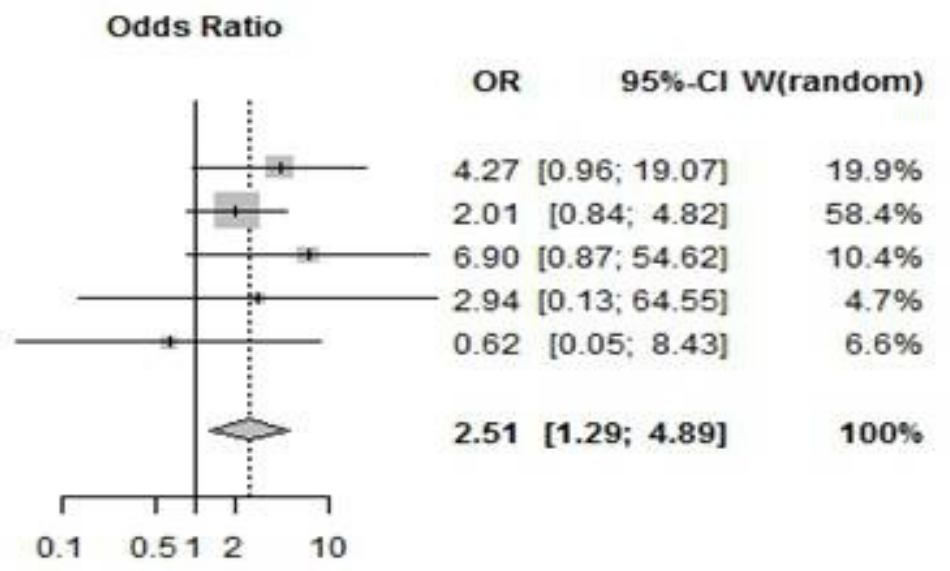

C Combination therapy Monotherapy
Study
Events Total Events Total

Odds Ratio

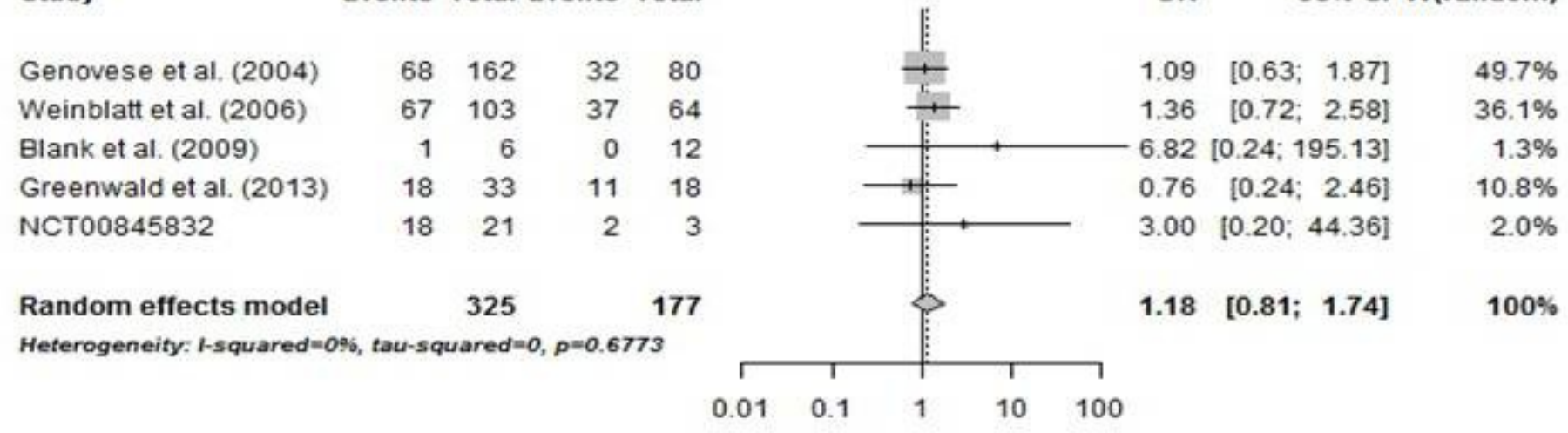

D

Study

Combination therapy Monotherapy Events Total Events Total

Genovese et al. (2004)

Weinblatt et al. (2006)

Weinblatt et al. (2007)

Blank et al. (2009)

Greenwald et al. (2013)

NCT00845832

$\begin{array}{rr}9 & 162 \\ 6 & 103 \\ 3 & 85 \\ 0 & 6 \\ 3 & 33 \\ 1 & 21\end{array}$

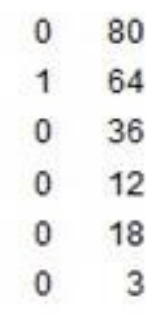

Odds Ratio

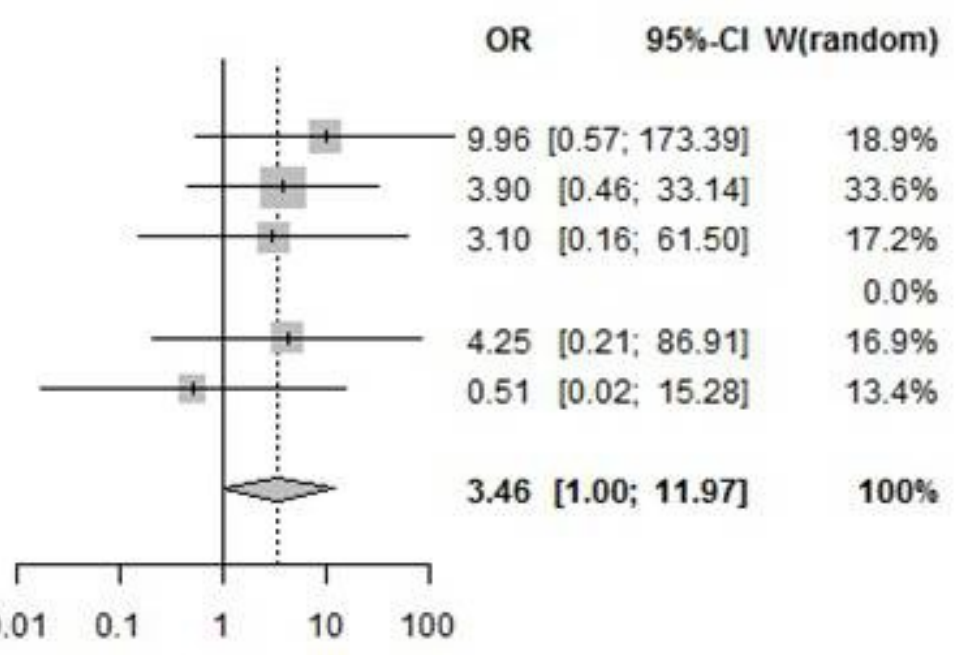

Random effects model

410

Heterogeneity: 1 -squared $=0 \%$, tau-squared $=0, p=0.7631$ 


\section{Figure 3}

Combination therapy Monotherapy Events Total Events Total

$\begin{array}{rrrr}76 & 81 & 72 & 80 \\ 98 & 103 & 57 & 64 \\ 31 & 33 & 15 & 18\end{array}$

Weinblatt et al. (2006)

$31 \quad 33$

1518

Random effects mode

217

Heterogeneity: 1 -squared $=0 \%$, tau-squared $=0, \rho=0.8421$

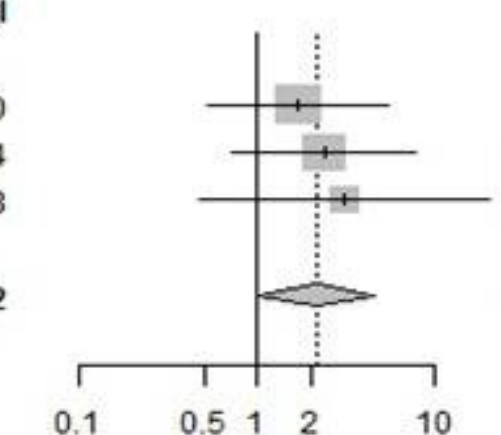

$\begin{array}{lllll}0.1 & 0.5 & 1 & 2 & 10\end{array}$

$1.69[0.53 ; 5.40]-43.0 \%$

$2.41[0.73 ; 7.94] \quad 40.8 \%$

$3.10[0.47 ; 20.57] \quad 16.2 \%$

$2.15[1.00 ; 4.62] \quad 100 \%$

B

Combination therapy Monotherapy

Study

Events Total Events Total

$\begin{array}{lrrrr}\text { Genovese et al. (2004) } & 12 & 81 & 2 & 80 \\ \text { Weinblatt et al. (2006) } & 23 & 103 & 8 & 64 \\ \text { Greenwald et al. (2013) } & 2 & 33 & 0 & 18 \\ & & & & \\ \begin{array}{l}\text { Random effects model } \\ \text { Heterogeneity: } 1 \text {-squared }=0 \% \text {, tau-squared }=0, p=0.3966\end{array}\end{array}$

Heterogeneity: 1 -squared $=0 \%$, tau-squared $=0, p=0.3966$

C

\begin{tabular}{|c|c|c|c|c|}
\hline \multirow[b]{2}{*}{ Study } & \multicolumn{4}{|c|}{ ation therapy $n$} \\
\hline & Events & Total & ents & Total \\
\hline Genovese et al. (2004) & 38 & 81 & 32 & 80 \\
\hline Weinblatt et al. (2006) & 67 & 103 & 37 & 64 \\
\hline Blank et al. (2009) & 1 & 6 & 0 & 12 \\
\hline Greenwald et al. (2013) & 18 & 33 & 11 & 18 \\
\hline indom effects model & & 223 & & \\
\hline
\end{tabular}

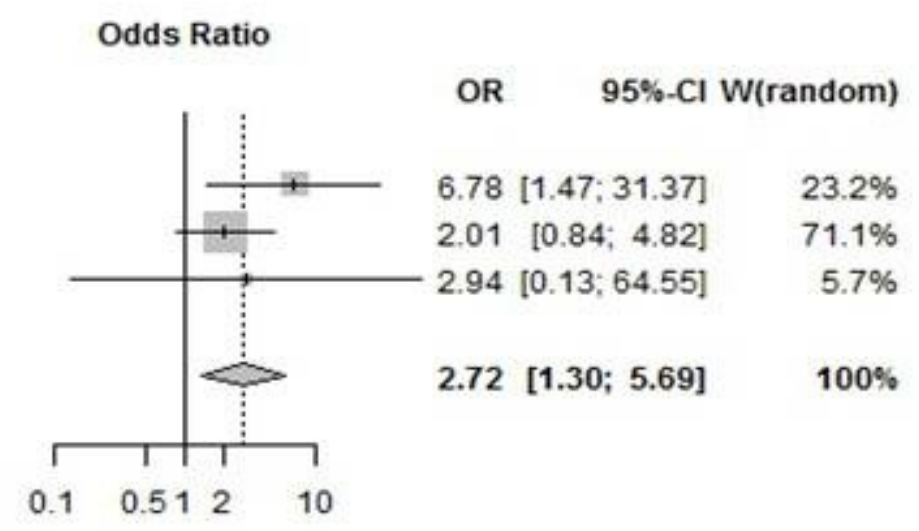

Odds Ratio

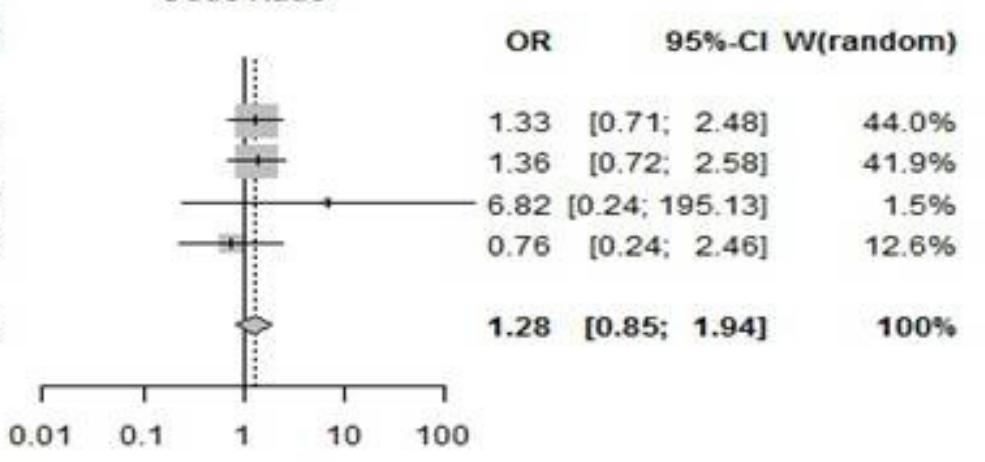

D

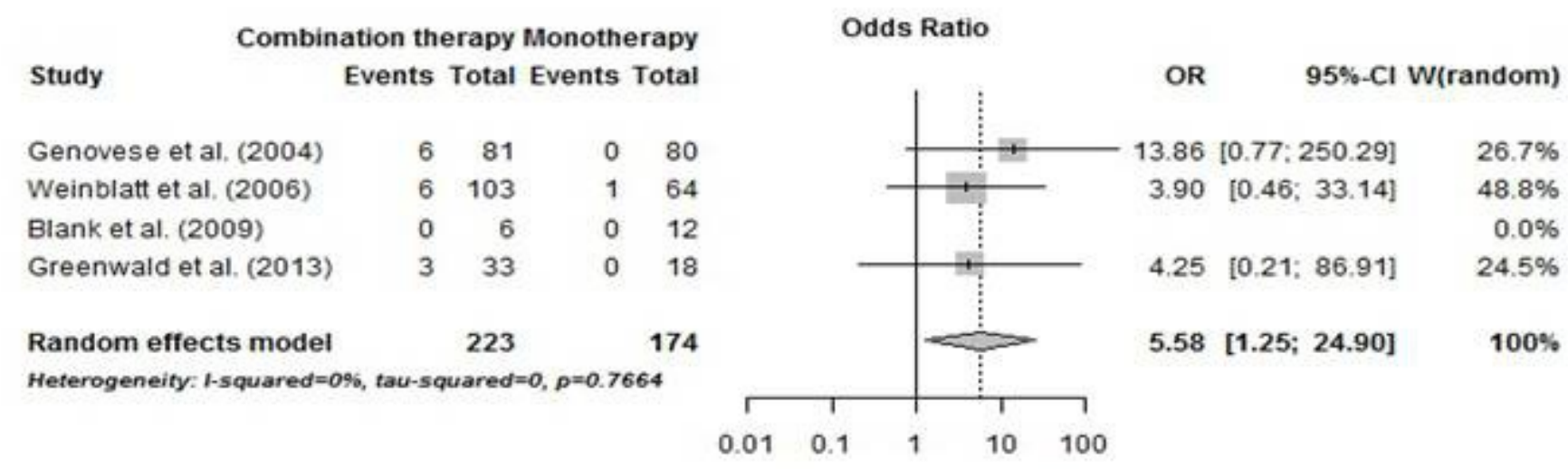




\begin{tabular}{|c|c|c|c|c|c|c|c|c|c|c|}
\hline Table 1 & ummary of studic & acluded in metc & nalysis & & & & & & & \\
\hline $\begin{array}{l}\text { Author/Year } \\
\text { published }\end{array}$ & $\begin{array}{c}\text { Country } \\
\text { (single/ } \\
\text { multicentre) }\end{array}$ & Design & $\begin{array}{c}\text { Follow-up } \\
\text { period } \\
\text { (months) }\end{array}$ & $\begin{array}{l}\text { Patients } \\
\text { (n) }\end{array}$ & Combination arm & Control arm & $\begin{array}{c}\text { Mean age } \\
\text { combination arm, } \\
\text { years }\end{array}$ & $\begin{array}{c}\text { Mean age } \\
\text { control arm, } \\
\text { years }\end{array}$ & $\begin{array}{l}\text { Primary } \\
\text { outcome }\end{array}$ & $\begin{array}{c}\text { Safety } \\
\text { outcomes }\end{array}$ \\
\hline $\begin{array}{c}\text { Genovese et al, } \\
2004\end{array}$ & $\begin{array}{c}\text { USA } \\
\text { (multicentre) }\end{array}$ & RCT & 6 & 242 & $\begin{array}{l}\text { Etanercept } \\
+ \text { Anakinra }\end{array}$ & Etanercept alone & $\begin{array}{l}53.8 \text { (half-dosage) } \\
55.7 \text { (full-dosage) }\end{array}$ & 54.4 & $\begin{array}{c}\text { ACR } 50 \\
\text { at week } 24\end{array}$ & $\begin{array}{c}\text { Increased rate of } \\
\text { SAEs }\end{array}$ \\
\hline $\begin{array}{l}\text { Weinblatt et al, } \\
2006\end{array}$ & $\begin{array}{c}\text { USA } \\
\text { (multicentre) }\end{array}$ & RCT & 12 & 167 & $\begin{array}{c}\text { Abatacept }+ \text { TNFi or } \\
\text { Abatacept }+ \text { Anakinra }\end{array}$ & $\begin{array}{l}\text { TNFi or Anakinra + } \\
\text { Placebo }\end{array}$ & 54.6 & 52.8 & Safety & $\begin{array}{c}\text { Increased rate of } \\
\text { SAEs }\end{array}$ \\
\hline $\begin{array}{l}\text { Weinblatt et al, } \\
2007\end{array}$ & $\begin{array}{c}\text { USA } \\
\text { (multicentre) }\end{array}$ & RCT & 12 & 121 & $\begin{array}{l}\text { Abatacept } \\
+ \text { Etanercept }\end{array}$ & Etanercept + Placebo & 49.8 & 54.3 & $\begin{array}{l}\text { ACR } 20 \\
\text { at } 6 \text { months }\end{array}$ & $\begin{array}{l}\text { Increased rate of } \\
\text { SAEs }\end{array}$ \\
\hline $\begin{array}{l}\text { Blank et al, } \\
2009\end{array}$ & $\begin{array}{c}\text { Germany } \\
\text { (single-centre) }\end{array}$ & $\begin{array}{l}\text { retrospective } \\
\text { cohort }\end{array}$ & 8 & 18 & Rituximab + Etanercept & Rituximab alone & 47.0 & 55.5 & Safety & $\begin{array}{c}\text { No increased risk } \\
\text { of } \\
\text { SAEs }\end{array}$ \\
\hline $\begin{array}{c}\text { Greenwald et al, } \\
2013\end{array}$ & $\begin{array}{c}\text { USA } \\
\text { (multicentre) }\end{array}$ & RCT & 6 & 51 & $\begin{array}{c}\text { TNFi } \\
+ \text { Rituximab }\end{array}$ & TNFi + Placebo & 49.7 & 50.4 & Safety & $\begin{array}{c}\text { No increased risk } \\
\text { of } \\
\text { SAEs }\end{array}$ \\
\hline $\begin{array}{c}\text { NCT00845832, } \\
2013\end{array}$ & $\begin{array}{l}8 \text { European } \\
\text { countries } \\
\text { (multicentre) }\end{array}$ & RCT & 12 & 24 & $\begin{aligned} & \text { Rituximab } \\
+ & \text { Tocilizumab }\end{aligned}$ & Placebo + Tocilizumab & $\begin{array}{c}48.2(\text { tocilizumab } \\
0,2 \mathrm{mg} / \mathrm{kg} \text { ) } \\
50.0 \text { (tocilizumab } \\
0.4 \mathrm{mg} / \mathrm{kg} \text { ) }\end{array}$ & 41.3 & $\begin{array}{c}\text { LDA } \\
\text { at week } 16\end{array}$ & $\begin{array}{c}\text { No increased risk } \\
\text { of } \\
\text { SAEs }\end{array}$ \\
\hline
\end{tabular}

RCT, randomized, placebo-controlled double-blind trial; TNFi, tumor necrosis factor inhibitor; MTX, methotrexate; NR, not reported; ACR 50, American College of Rheumatology Response Criteria

50; ACR 20, American College of Rheumatology of Rheumatology Response Criteria 20; LDA, low disease activity; SAEs, serious adverse events 